Labate, S. (2014). Translating French into French: The case of Close Encounters of the Third Kind. Linguistica Antverpiensia, New Series. Themes in Translation Studies, 13, 193-210.

\title{
Translating French into French: The case of Close Encounters of the Third Kind ${ }^{1}$
}

\author{
Simon Labate \\ University of Namur and F.N.R.S. \\ simon.labate@unamur.be
}

This paper deals with the French dubbed version of Steven Spielberg's 1977 Close Encounters of the Third Kind. The film features a scientist who mainly speaks French and is helped by an interpreter, who often translates simultaneously or consecutively from French into English and vice versa. In the French dub, however, all the characters speak French, which is why the original redundancy created by the interpreting acts had to be avoided at all cost. The analysis of a number of scenes makes it possible to identify the various translation strategies applied to conceal the original multilingual situations. The textual modifications carried out to produce a coherent French script have repercussions on the image of the scientist and his interpreter as characters in the film.

\section{Introduction}

In 1977 the history of cinema was changed forever, thanks to the groundbreaking special effects featured in Star Wars, ${ }^{2}$ a space opera directed by George Lucas. Later that year, another gifted director and good friend of Lucas, Steven Spielberg, also released a critically and commercially successful science fiction film, Close Encounters of the Third Kind $(C E 3 K)$. Whereas the former film is a war epic taking place in a "galaxy far, far away", $C E 3 K$ is set in the United States and takes a more intimate approach, its overarching theme being the search for contact between human beings and extra-terrestrials. The main storyline focuses on Roy Neary (played by Richard Dreyfuss), a lineman who experiences a so-called 'close encounter' with a UFO. He quickly develops an obsession for such objects and starts experiencing visions about a mountain. Meanwhile, scientists from all over the world, among whom the French ufologist Claude Lacombe (François Truffaut), gather information about strange sightings and decode a five-note message indicating the geographical coordinates for a rendezvous at Devils Tower, Wyoming, where the two storylines converge for the grand finale.

$C E 3 K$ has a multilingual setup: due to his poor proficiency in English, Lacombe has to rely on an interpreter, David Laughlin (played by Bob Balaban), originally a mapmaker who has been recruited simply because of his knowledge of the French language. ${ }^{3}$ In the film, Laughlin 
frequently interprets between English and French, which means that a bilingual viewer hears the same message twice. However, for most monolingual Anglophone spectators unaccustomed to subtitled films, the presence of an interpreter in the story is an advantage: Laughlin's consecutive interpreting makes it possible to use a very limited number of subtitles. The questions addressed in this paper are: What happens in the French dubbed version of $C E 3 K$ ? How are the multilingual situations and scenes of intratextual translation (Zabalbeascoa, 2012) dealt with?

In the course of the past 25 years, a growing number of scholars have become interested in the translation of audiovisual productions. Their research has resulted in a sizeable number of articles and books (e.g., Abend-David, 2014; Armstrong \& Federici, 2005; Díaz Cintas et al., 2010 ; Gambier \& Gottlieb, 2001; Orero, 2004; Remael et al., 2013 ; Şerban \& Lavaur, 2011) and the publication of special issues in renowned journals in the field of Translation Studies such as Babel, Meta, Target and The Translator. Audiovisual Translation Studies (AVT) has grown into a discipline in its own right and the range of subjects is more diversified than ever.

Quite recently, a particular phenomenon in film has attracted the attention of AVT researchers: heterolingualism, the "motivated deployment of multiple languages in fiction", not to be confused with "sociolinguistic multilingualism as in diglossia or code-switching" (O'Sullivan, 2011, p. 20). A number of translation scholars (e.g., Delabastita \& Grutman, 2005; Meylaerts, 2006) have discussed heterolingualism in translated literary and audiovisual texts. Some studies have focused on the translation of language difference in films. For instance, Bleichenbacher (2008) conducted a statistical analysis of a corpus of 28 films in order to determine the influence of multilingualism on characterisation. Corrius (2008) has described the various facets of the translation of multilingual audiovisual texts. O'Sullivan (2011) has given a detailed account of the various devices used to represent foreign languages in the history of film. Corrius and Zabalbeascoa (2011) have proposed a taxonomy of translation strategies for 'third languages' (L3s, i.e., foreign languages) and Voellmer (2012) has demonstrated its applicability by analysing the original, German, Italian and Spanish dubbed versions of Inglourious Basterds (Tarantino, 2009).

Film dubbing typically implies that all the spoken verbal elements (or 'lines') in the source language (L1) are translated into the target language (L2). However, this standard definition does not account for the frequent occurrences of L3s. Heterolingualism should be considered as a distinct textual feature for which specific translation strategies are applied, just as such phenomena as intertextuality, humour and poetry are treated in a particular fashion. According to Bleichenbacher (2008, pp. 23-25), heterolingualism can manifest itself in various ways, ranging from presence (what Sternberg [1981] labels as 'vehicular matching') to elimination (i.e., the absence of heterolingualism, also known as 
homogenisation [O’Sullivan, 2011, pp. 26-28]) or in-between strategies such as evocation (the recreation of heterolingualism via phonological, lexical and grammatical devices) and signalisation (a homo- or heterodiegetic reference to the real-world language difference). Depending on the demands of the director(s), producer(s) or distributor(s) of a film, its translator(s) will have to use one of these strategies to deal with instances of heterolingualism. For example, The Longest Day (Annakin et al., 1962) portrays the D-Day operations from the point of view of American, English, French and German protagonists, who all speak in their native tongues (presence). In the French dubbed version, however, the German characters speak French with a thick accent (evocation); in contrast, the difference between American and British soldiers can be inferred only from verbal and visual clues (signalisation), since they all speak standard French (elimination). Much of the original heterolingual nature of the film therefore disappears in the French version (Labate, 2013a).

The French dubbed version of $C E 3 K$ constitutes a particular case of the translation of heterolingualism in that the original version's main L3 coincides with the target language. The translators ${ }^{4}$ decided to carry out textual modifications not only to hide the original multilingual setup, but also to conceal the instances of interpreting. In this article I set out to identify the strategies used to produce a dubbed text that seems coherent.

\section{Methodology}

To investigate the research question, I worked on the scenes that feature Lacombe and/or Laughlin. I made a line-by-line comparison of the original $(\mathrm{OV})$ and the French dubbed version (FDV) by noting the language(s) spoken, the type of action that Laughlin is performing, and all the occurrences of heterolingualism.

Some 23 scenes $^{5}$ were scrutinised and a total of 431 lines were distinguished: in absolute terms the scenes feature 221 lines, but since six lines were added in the FDV, the OV actually amounts to 215 lines; similarly, five lines did not make it into the FDV, which is why the latter contains 216 lines.

The so-called 'Collector's Edition' from 2001 was used for this research. Indeed, $C E 3 K$ had an unstable textual history: a first version was released in November 1977 and three years later Steven Spielberg was able to make a director's cut version (the 'Special Edition') on condition that he add a scene inside the alien mother ship at the end of the film. However, Spielberg was dissatisfied with that ending and edited another version (the 'Collector's Edition') that was released on laserdisc in 1997 and on DVD in 2001. The director considers this version as definitive and therefore as authoritative, which is why I chose it for my analysis. 
As a consequence, I analysed the $2001 \mathrm{FDV}$ : while $C E 3 K$ had already been dubbed in 1977, the French distributor decided to redub the film for its DVD release. This means that all the lines were re-recorded, sometimes with minor changes in the text, except for Lacombe's lines. Indeed, François Truffaut would not have been able to lend his voice to the character a second time because he passed away in 1984; if another voice actor had dubbed him, the French audience would have been disappointed not to hear this legend of French cinema speak with his own voice. $^{6}$

Redubbing is not an unusual practice in the French cinema industry. On the one hand, it is often used to 'modernise' the voices and achieve better sound quality standards (through audio remastering), as is the case with The Towering Inferno (Guillermin, 1974) and many Disney classics such as Snow White and the Seven Dwarfs (Hand, 1937), which was even redubbed twice. On the other hand, the presence of additional scenes in cinema reissues makes it necessary to redub certain films to ensure voice consistency between the old and the new scenes, as in the 20th anniversary re-release of E.T. the Extra-Terrestrial (Spielberg, 1982). This situation sometimes causes disappointment among the French-speaking fans, who complain about the loss of the original flavour of the first FDVs. Fortunately, some DVD or Blu-ray editions feature both the original and the new FDVs (as well as the OVs) of the same film, giving the viewers the choice to watch whichever version they prefer.

\section{Results}

In what follows, I discuss quantitative data from the multilingual scenes. I then conduct a qualitative, textual analysis in view of unearthing those translation strategies that were used in the 2001 dub.

\subsection{Quantitative analysis}

In order to form a general picture of the scenes analysed, it is worth mapping out the languages that can be heard in them. Table 1 shows the distribution of languages in each line of the OV.

Table 1: Languages present in the OV scenes $(n=215)$.

\begin{tabular}{|l|l|l|l|l|}
\hline English & French & $\begin{array}{l}\text { English and } \\
\text { French }\end{array}$ & Hindi & Spanish \\
\hline $120(55.81 \%)$ & $78(36.28 \%)$ & $11(5.12 \%)$ & $2(0.93 \%)$ & $4(1.86 \%)$ \\
\hline
\end{tabular}


Lines in English make up only just over half (56\%) of the total; some 5\% of bilingual lines can be added to that. A total of 95 lines (44\%) are (sometimes partly) in a foreign language, which is quite considerable. Two of these lines are in Hindi and four in Spanish. The situation is quite different in the FDV, as can be seen in Table 2.

Table 2: Languages present in the FDV scenes $(\mathrm{n}=216)$.

\begin{tabular}{|l|l|l|}
\hline French & Hindi & Spanish \\
\hline $209(96.76 \%)$ & $3(1.39 \%)$ & $4(1.85 \%)$ \\
\hline
\end{tabular}

Unsurprisingly, English has completely disappeared because L2 has replaced L1. The number of lines in Spanish remains the same; the two lines originally in Hindi are preserved and one more is added. Table 3 below presents an excerpt from the scene where Lacombe and the research group on UFOs are in India to record mysterious chants; the back translation (BT) is given in the right column and "[?]" indicates that the words were indecipherable:

Table 3: Excerpt from the Indian scene.

\begin{tabular}{|c|c|c|c|}
\hline Character & $\mathrm{OV}$ & FDV & $\mathrm{BT}$ \\
\hline Lacombe & $\begin{array}{l}\text { Je veux savoir d'où } \\
\text { vient cette musique. }\end{array}$ & $\begin{array}{l}\text { Je veux savoir d'où } \\
\text { vient cette } \\
\text { musique... }\end{array}$ & $\begin{array}{l}\text { I want to know } \\
\text { where this music } \\
\text { comes from. }\end{array}$ \\
\hline Laughlin & {$[?]$} & Venez avec nous. & Come with us. \\
\hline Lacombe & [?] ... cette musique. & $\begin{array}{l}\ldots \text { de quelle } \\
\text { direction. }\end{array}$ & $\begin{array}{l}\ldots \text { from which } \\
\text { direction. }\end{array}$ \\
\hline Laughlin & {$[?]$} & Namaste babu. & Greetings, sir. \\
\hline Lacombe & $\begin{array}{l}\text { D'où viennent ces } \\
\text { sons? }\end{array}$ & $\begin{array}{l}\text { D'où viennent ces } \\
\text { sons? }\end{array}$ & $\begin{array}{l}\text { Where are these } \\
\text { sounds coming } \\
\text { from? }\end{array}$ \\
\hline Laughlin & Where are [?] & $\begin{array}{l}\text { Je n'ai pas le } \\
\text { vocabulaire... }\end{array}$ & $\begin{array}{l}\text { I don't know the } \\
\text { words... }\end{array}$ \\
\hline Lacombe & $\begin{array}{l}\text { Demandez-lui d'où } \\
\text { viennent ces sons. }\end{array}$ & $\begin{array}{l}\text { Je veux savoir d'où } \\
\text { viennent ces sons. }\end{array}$ & $\begin{array}{l}\text { I want to know } \\
\text { where these sounds } \\
\text { come from. }\end{array}$ \\
\hline Laughlin & $\begin{array}{l}\text { Where were the } \\
\text { sounds coming } \\
\text { from? }\end{array}$ & $\begin{array}{l}\text { Est-ce que vous } \\
\text { voulez bien lui poser } \\
\text { la question, s'il vous } \\
\text { plaît? }\end{array}$ & $\begin{array}{l}\text { Would you mind } \\
\text { asking him the } \\
\text { question, please? }\end{array}$ \\
\hline
\end{tabular}


In the OV, Laughlin translates Lacombe's questions into English for an Indian interpreter, although the former's voice cannot be heard clearly because of the background noises. In contrast, in the FDV Laughlin tries to make contact by using the Namaste salutation, before realising that he is lost for words. As a result, he comes across as an awkward and unnecessary intermediary because the Indian interpreter should already have understood Lacombe.

In order to quantify heterolingualism in both versions of $C E 3 K$, I counted the lines which met at least one of the following criteria: the presence of a word/several words in another language than English (in the $\mathrm{OV}$ ) or French (in the FDV), the foreign pronunciation of a word/several words, and any textual references to languages. The results are shown in Table 4.

Table 4: Heterolingualism in the OV and FDV.

\begin{tabular}{|l|l|l|}
\cline { 2 - 3 } \multicolumn{1}{c|}{} & Absence & Presence \\
\hline Original version & 99 & 116 \\
\hline French dubbed version & 203 & 13 \\
\hline
\end{tabular}

A majority (54\%) of OV lines in the scenes display some degree of heterolingualism, mainly because of the situations where interpreting is involved. The FDV, on the other hand, is strongly monolingual since only $6 \%$ of its lines feature a language other than French or hint at a multilingual context (e.g., "Non, je ne comprends pas l'espagnol", i.e., "No, I don't understand Spanish"). Table 5 presents the distribution of the languages used by Lacombe and Laughlin:

Table 5: Languages used by Lacombe and Laughlin in the OV and FDV.

\begin{tabular}{|l|l|l|l|l|l|}
\cline { 3 - 6 } \multicolumn{2}{c|}{} & English & French & Eng. \& Fr. & Hindi \\
\hline \multirow{3}{*}{ Lacombe } & OV & $11(15 \%)$ & $54(74 \%)$ & $8(11 \%)$ & 0 \\
\cline { 2 - 6 } & FDV & 0 & $76(100 \%)$ & 0 & 0 \\
\hline \multirow{3}{*}{ Laughlin } & OV & $51(68 \%)$ & $20(27 \%)$ & $4(5 \%)$ & 0 \\
\cline { 2 - 6 } & FDV & 0 & $75(99 \%)$ & 0 & $1(1 \%)$ \\
\hline
\end{tabular}

In the OV Lacombe mainly expresses himself in French; he considers his command of English imperfect and relies on Laughlin to interpret between him and his interlocutors. However, Lacombe occasionally does speak English, using simple words or sentences (e.g., "Sunburn?", "Hello", "Thank you very much", "I am Claude Lacombe") or when he reacts promptly (e.g., "Go outside and make me a liar", "Because this means something"). In one scene (Table 6), Lacombe addresses an 
international audience in English at a talk he gives about his sign language codification of the extra-terrestrial musical message:

Table 6: Excerpt from the speech scene.

\begin{tabular}{|c|c|c|}
\hline OV & FDV & BT \\
\hline $\begin{array}{l}\text { Good evening, ladies and } \\
\text { gentlemen. Parlez-vous } \\
\text { français? Well... I beg } \\
\text { your pardon, but my } \\
\text { English is not good too. } \\
\text { [laughter] }\end{array}$ & $\begin{array}{l}\text { Mesdames et Messieurs } \\
\text { bonsoir. J'espère que... } \\
\text { vous parlez tous le } \\
\text { français? Merci. Il est } \\
\text { possible qu'un jour, nous } \\
\text { parlerons tous un langage } \\
\text { codé. }\end{array}$ & $\begin{array}{l}\text { Ladies and gentlemen, } \\
\text { good evening. I hope } \\
\text { that... you all speak } \\
\text { French? Thanks. It's } \\
\text { possible that someday we } \\
\text { will all speak a coded } \\
\text { language. }\end{array}$ \\
\hline
\end{tabular}

Lacombe starts off in English, says something in French, then switches back to English and apologises for his poor knowledge of this language to an understanding crowd (as evidenced by the laughter in the audience); a few moments later, he reverts to French to explain the hand signs. By way of contrast, in the FDV Lacombe makes sure that his audience understands French and goes on to speculate about the advent of a universal coded language. Although this eventuality is in line with the sign language passage that follows, the fact that Lacombe mentions French while standing in front of a large American flag could be perceived by some FDV viewers as incongruous. ${ }^{7}$ All other references to the American context are deleted, for example, "He isn't even an American" becomes "Lui? Qu'est-ce qui me prouve que c'est vrai?" (i.e., "Him? How can I be sure it's true?").

Moreover, some of Lacombe's utterances are in English (with a thick French accent) because they are important statements in the film; these lines are always found at the end of a scene: "It's still a mystery to me why they are here. Even they do not know why", "Listen to me, Major Walsh: it is an event sociological" [sic], "They belong here more than we"). The fact that Lacombe himself speaks English gives more weight to these statements, making it possible to avoid another translation/repetition by Laughlin in the OV, and it highlights Lacombe's importance vis-à-vis Laughlin in the story. These narrative features created by the heterolingual setup completely disappear in the FDV, where French is heard throughout, and a series of new situations are created. In what follows, I examine the different translation strategies used in $C E 3 K^{\prime} \mathrm{s}$ FDV and identify the repercussions they have on the way in which characters are portrayed. 


\subsection{Qualitative analysis}

In the OV, Laughlin utters a total of 75 lines, 57 of which belong to a translation act, the others being questions or answers to fellow Americans; he speaks more than twice as often in English (51 lines) as in French (20 lines). In the FDV Laughlin speaks only French (and a few words of Hindi, see Table 3), thanks to a number of strategies used by the translators to conceal the original occurrences of interpreting. The most frequently used method in the scenes analysed consists in having Laughlin utter personal comments: in 21 lines he gives his opinion on what has just been said. This is the case, for instance, in the scene (see Table 7) in which the Project Leader ${ }^{8}$ questions an old man who witnessed a strange phenomenon in Spanish; here Laughlin interprets simultaneously and consecutively into French:

Table 7: Excerpt from the old man scene.

\begin{tabular}{|c|c|c|c|}
\hline Character & $\mathrm{OV}$ & FDV & BT \\
\hline $\begin{array}{l}\text { Mexican } \\
\text { officer }\end{array}$ & $\begin{array}{l}\text { ¡Dígale lo que pasó! } \\
\text { El viejito lo vio todo } \\
\text { anoche. }\end{array}$ & $\begin{array}{l}\text { ¡Dígale lo que pasó! } \\
\text { El viejito lo vio todo } \\
\text { anoche. }\end{array}$ & $\begin{array}{l}\text { Tell what happened! } \\
\text { The old man saw it } \\
\text { all last night! }\end{array}$ \\
\hline $\begin{array}{l}\text { Project } \\
\text { Leader }\end{array}$ & $\begin{array}{l}\text { He says this guy is } \\
\text { local, he was here } \\
\text { last night, he saw it } \\
\text { happen. }\end{array}$ & $\begin{array}{l}\text { Il dit que cet homme } \\
\text { est du village voisin } \\
\text { et qu'hier soir il a vu } \\
\text { ce qui s'est passé. }\end{array}$ & $\begin{array}{l}\text { He says this guy is } \\
\text { from the next village } \\
\text { and that he saw what } \\
\text { happened yesterday. }\end{array}$ \\
\hline Laughlin & $\begin{array}{l}\text { [simultaneously] Il } \\
\text { dit que... qu'il habite } \\
\text { ici, qu'il était ici hier } \\
\text { soir, qu'il a vu se } \\
\text { passer. [sic] }\end{array}$ & $\begin{array}{l}\text { Il a effectué le } \\
\text { premier contact; je } \\
\text { crois qu'il serait utile } \\
\text { de noter son } \\
\text { témoignage. }\end{array}$ & $\begin{array}{l}\text { He made the first } \\
\text { contact; I think it } \\
\text { would be useful to } \\
\text { write down his } \\
\text { testimony. }\end{array}$ \\
\hline $\begin{array}{l}\text { Project } \\
\text { Leader }\end{array}$ & $\begin{array}{l}\text { ¡Dígame qué vio! } \\
\text { ¿Qué le ha pasado? } \\
\text { [bis] ¿Por cuánto } \\
\text { tiempo va a estar } \\
\text { sentado usted aquí? } \\
\text { [sic] ¿Usted vive } \\
\text { alrededor de aquí? } \\
\text { ¡Viejo, dígame! }\end{array}$ & $\begin{array}{l}\text { ¡Dígame qué vio! } \\
\text { ¿Qué le ha pasado? } \\
\text { [bis] ¿Por cuánto } \\
\text { tiempo va a quedarse } \\
\text { aquí señor? ¿Usted } \\
\text { vive alrededor de } \\
\text { aquí? ¡Viejo, } \\
\text { dígame! }\end{array}$ & $\begin{array}{l}\text { Tell me what you } \\
\text { saw! What } \\
\text { happened? [bis] How } \\
\text { long [OV] are you } \\
\text { going to be sitting } \\
\text { here? / [FDV] will } \\
\text { you be staying here? } \\
\text { Do you live around } \\
\text { here? Old man, tell } \\
\text { me! }\end{array}$ \\
\hline Lacombe & $\begin{array}{l}\text { Sunburn? Oh, } \\
\text { regardez, il est brûlé, } \\
\text { le pauvre homme. }\end{array}$ & $\begin{array}{l}\text { Il est brûlé. } \\
\text { Regardez, il est } \\
\text { brûlé, là, le pauvre } \\
\text { homme. }\end{array}$ & $\begin{array}{l}\text { He's sunburnt. Look, } \\
\text { he's sunburnt, there, } \\
\text { that poor man. }\end{array}$ \\
\hline
\end{tabular}




\begin{tabular}{|l|l|l|l|}
\hline Old man & $\begin{array}{l}\text { El sol salió anoche y } \\
\text { me cantó. [bis] }\end{array}$ & $\begin{array}{l}\text { El sol salió anoche y } \\
\text { me cantó. [bis] }\end{array}$ & $\begin{array}{l}\text { The sun came out } \\
\text { last night and sang to } \\
\text { me. }\end{array}$ \\
\hline $\begin{array}{l}\text { Project } \\
\text { Leader }\end{array}$ & $\begin{array}{l}\text { He says the sun came } \\
\text { out last night. He } \\
\text { says it sang to him. }\end{array}$ & $\begin{array}{l}\text { Il dit que le soleil } \\
\text { s'est levé la nuit } \\
\text { dernière. Que le } \\
\text { soleil a chanté pour } \\
\text { lui. }\end{array}$ & $\begin{array}{l}\text { He says the sun came } \\
\text { out last night. That } \\
\text { the sun sang to him. }\end{array}$ \\
\hline Laughlin & $\begin{array}{l}\text { Il dit que le soleil } \\
\text { était venu hier soir et } \\
\text { qu'il chantait pour } \\
\text { lui. }\end{array}$ & $\begin{array}{l}\text { Vous savez, il est de } \\
\text { tradition dans ces } \\
\text { pays d'adorer le } \\
\text { soleil. Cela dit, c'est } \\
\text { toujours un } \\
\text { témoignage. }\end{array}$ & $\begin{array}{l}\text { You know, in these } \\
\text { countries it is a } \\
\text { tradition to worship } \\
\text { the sun. Mind you, } \\
\text { it's still a testimony. }\end{array}$ \\
\hline
\end{tabular}

The Project Leader's line in Spanish was dubbed in the FDV to ensure voice continuity with other scenes, although its content was slightly modified, from a Mexican Spanish utterance ("¿Por cuánto tiempo va a estar sentado usted aquí?", with explicit "usted") to a more European Spanish one ("¿Por cuánto tiempo va a quedarse aquí señor?"). Although both sentences express essentially the same meaning, they are incongruous: the Project Leader asks the old man whether he will stay there, while logically he should be interrogating him about past events. ${ }^{9}$

In the OV, the Project Leader translates the Spanish utterances into English, then Laughlin interprets them into French for Lacombe; to my knowledge, this is a very rare instance of double consecutive interpreting in a film. In the FDV, Laughlin suggests making a note of the old man's testimony and mentions a "premier contact" (i.e., 'first contact'), which is in fact a kind of anticipation with respect to the rest of the story. Indeed, this exchange takes place at the very beginning of the film, when Laughlin has just joined the project and has not yet been informed about its goals (i.e., finding out about the UFOs and the extra-terrestrial messages). At the end of the scene, his words seem to dismiss what the old man has said, attributing it to local superstitions; this contradicts the previous anticipatory remark suggesting a close encounter with aliens.

Other examples of personal comments are reproduced in Table 8, which contains an excerpt from the scene in which Lacombe and Laughlin ask Neary about his reasons for wanting to reach Devils Tower. 
Table 8: Excerpt from the interrogation scene.

\begin{tabular}{|c|c|c|c|}
\hline Character & $\mathrm{OV}$ & FDV & BT \\
\hline Lacombe & $\begin{array}{l}\text { En venant ici, vous } \\
\text { vous exposez aux } \\
\text { gaz toxiques. }\end{array}$ & $\begin{array}{l}\text { En venant ici, vous } \\
\text { vous exposez aux } \\
\text { gaz toxiques. }\end{array}$ & $\begin{array}{l}\text { In coming here, } \\
\text { you've exposed } \\
\text { yourself to toxic gas. }\end{array}$ \\
\hline Laughlin & $\begin{array}{l}\text { In coming here, } \\
\text { you've exposed } \\
\text { yourself to toxic gas. }\end{array}$ & $\begin{array}{l}\text { J'imagine que vous } \\
\text { avez de bonnes } \\
\text { raisons de courir ce } \\
\text { genre de risques. }\end{array}$ & $\begin{array}{l}\text { I guess that you have } \\
\text { good reasons to take } \\
\text { such a risk. }\end{array}$ \\
\hline Neary & Well, I'm alive. & Mais je suis vivant... & But I'm alive... \\
\hline Laughlin & Je suis vivant. & Oui, je le vois bien. & Yes, I can see that. \\
\hline Neary & We're talking. & ... et je vous parle. & $\begin{array}{l}\ldots \text { and I'm talking to } \\
\text { you. }\end{array}$ \\
\hline Laughlin & Nous parlons. & I's'rend pas compte. & He doesn't get it. \\
\hline Lacombe & $\begin{array}{l}\text { C'est vrai, Monsieur } \\
\text { Neary. }\end{array}$ & $\begin{array}{l}\text { Vous avez beaucoup } \\
\text { de chance. }\end{array}$ & You're very lucky. \\
\hline Laughlin & $\begin{array}{l}\text { This is true, } \mathrm{Mr} \\
\text { Neary. }\end{array}$ & $\begin{array}{l}\text { C'est vrai, beaucoup } \\
\text { de chance. }\end{array}$ & Very lucky indeed. \\
\hline
\end{tabular}

In the OV, Laughlin simply translates back and forth, while in the FDV he makes patronising remarks, using a scornful, cynical tone (for instance, when he says "Il ne se rend pas compte", contracted into "I's'rend pas compte"), as if he wanted to undermine Neary's testimony at all cost. Voellmer (2012, pp. 70-72) identified a similar strategy in a scene from the German dubbed version of Inglourious Basterds (Tarantino, 2009) featuring an American interrogating a German soldier with the help of an interpreter.

Another frequently used translation device in $C E 3 K$ 's FDV is development: Laughlin expands on a particular idea and/or gives additional details. This phenomenon always occurs after Lacombe has spoken, that is, when, in the OV, Laughlin was originally translating the former's words into English. Table 9 features an example of this, with Lacombe begging Major Walsh not to get rid of the people who felt unconsciously compelled to go to Devils Tower: 
Table 9: Excerpt from the headquarters scene.

\begin{tabular}{|c|c|c|c|}
\hline Character & $\mathrm{OV}$ & FDV & BT \\
\hline Lacombe & $\begin{array}{l}\text { Moi non plus je ne } \\
\text { sais pas ce qui se } \\
\text { passe et j'aimerais } \\
\text { bien qu'on } \\
\text { m'explique tout cela. }\end{array}$ & $\begin{array}{l}\text { Moi non plus je ne } \\
\text { sais pas ce qui se } \\
\text { passe et j'aimerais } \\
\text { bien qu'on } \\
\text { m'explique tout cela. }\end{array}$ & $\begin{array}{l}\text { I don't know what's } \\
\text { happening either and } \\
\text { I'd like someone to } \\
\text { explain it all to me. }\end{array}$ \\
\hline Laughlin & $\begin{array}{l}\text { I don't know what's } \\
\text { happening either. I } \\
\text { must find out what's } \\
\text { going out. }\end{array}$ & $\begin{array}{l}\text { Nous cherchons à } \\
\text { savoir pourquoi ils } \\
\text { ont été attirés à } \\
\text { Devils Tower. }\end{array}$ & $\begin{array}{l}\text { We'd like to find out } \\
\text { why they were drawn } \\
\text { to Devils Tower. }\end{array}$ \\
\hline Lacombe & $\begin{array}{l}\text { Je crois que pour } \\
\text { chaque personne } \\
\text { inquiète, angoissée, } \\
\text { tourmentée qui est } \\
\text { venue ici... }\end{array}$ & $\begin{array}{l}\text { Il ne s'agit pas } \\
\text { seulement de ces } \\
\text { douze personnes } \\
\text { inquiètes, angoissées, } \\
\text { tourmentées qui sont } \\
\text { venues jusqu'ici... }\end{array}$ & $\begin{array}{l}{[\mathrm{OV}] \text { I believe that }} \\
\text { for every worried, } \\
\text { anxious, tormented } \\
\text { person that has come } \\
\text { here... [FDV] It's not } \\
\text { just about those } \\
\text { twelve worried, } \\
\text { anxious, tormented } \\
\text { people who have } \\
\text { come here... }\end{array}$ \\
\hline Laughlin & $\begin{array}{l}\text { I believe that every } \\
\text { one of these anxious, } \\
\text { anguished people } \\
\text { who have come here } \\
\text { this evening... }\end{array}$ & $\begin{array}{l}\text { Il nous faut } \\
\text { déterminer la cause } \\
\text { de cette angoisse et } \\
\text { comment cet endroit } \\
\text { peut les en délivrer. }\end{array}$ & $\begin{array}{l}\text { We need to find out } \\
\text { the source of this } \\
\text { anxiety and how this } \\
\text { place can free them } \\
\text { from it. }\end{array}$ \\
\hline Lacombe & $\begin{array}{l}\text {... il y en a des } \\
\text { centaines d'autres qui } \\
\text { ont reçu la même } \\
\text { vision et qui ne sont } \\
\text { pas là. }\end{array}$ & $\begin{array}{l}\text { Il y a sûrement des } \\
\text { centaines d'autres à } \\
\text { qui on a implanté une } \\
\text { vision du même } \\
\text { genre... }\end{array}$ & $\begin{array}{l}{[\mathrm{OV}] \ldots \text {... there must }} \\
\text { be hundreds of others } \\
\text { who have received } \\
\text { the same vision and } \\
\text { who aren't there. } \\
\text { [FDV] There must be } \\
\text { hundreds of others } \\
\text { who had a similar } \\
\text { vision implanted... }\end{array}$ \\
\hline Laughlin & $\begin{array}{l}\ldots \text { there must be } \\
\text { hundreds of others } \\
\text { also touched by the } \\
\text { implanted vision who } \\
\text { never made it this far. }\end{array}$ & $\begin{array}{l}\text {... Qui ont peut-être } \\
\text { été traumatisés ou qui } \\
\text { n'ont pas eu } \\
\text { matériellement la } \\
\text { possibilité de venir. }\end{array}$ & $\begin{array}{l}\text {.. Who were maybe } \\
\text { traumatised or did } \\
\text { not have the material } \\
\text { possibility to come. }\end{array}$ \\
\hline
\end{tabular}


Lacombe's second and third lines in the dialogue reproduced above were modified in the FDV in order to obtain a fluent and coherent dialogue. This proved to be necessary in several other scenes from $C E 3 K$, for example in the exchange included in Table 10:

Table 10: Excerpt from the interrogation scene

\begin{tabular}{|l|l|l|l|}
\hline Character & OV & FDV & BT \\
\hline Laughlin & $\begin{array}{l}\text { [to Lacombe] Je } \\
\text { pensais... }\end{array}$ & $\begin{array}{l}\text { Alors qu'est-ce que } \\
\text { vous en pensez? }\end{array}$ & $\begin{array}{l}\text { So what do you } \\
\text { think? }\end{array}$ \\
\hline Lacombe & $\begin{array}{l}\text { Oui, qu'il connait la } \\
\text { montagne. [to } \\
\text { Neary] Monsieur } \\
\text { Neary, please, one } \\
\text { more question. } \\
\text { N'avez-vous pas fait } \\
\text { récemment une } \\
\text { rencontre? [finger } \\
\text { gesture to Laughlin] }\end{array}$ & $\begin{array}{l}\text { qu'il sait quelque } \\
\text { chose. Monsieur va } \\
\text { vous poser une } \\
\text { question si vous le } \\
\text { permettez. Une } \\
\text { question qui peut } \\
\text { vous sembler } \\
\text { incongrue. }\end{array}$ & $\begin{array}{l}\text { I have the feeling } \\
\text { that he knows } \\
\text { something. This } \\
\text { gentleman is going } \\
\text { to ask you a } \\
\text { question, if it's fine } \\
\text { with you. A question } \\
\text { that might sound } \\
\text { odd to you. }\end{array}$ \\
\hline Laughlin & $\begin{array}{l}\text { Have you recently } \\
\text { had a close } \\
\text { encounter? }\end{array}$ & $\begin{array}{l}\text { Oui, avez-vous fait } \\
\text { ces derniers temps } \\
\text { une rencontre? }\end{array}$ & $\begin{array}{l}\text { Yes, have you } \\
\text { recently had a close } \\
\text { encounter? }\end{array}$ \\
\hline
\end{tabular}

The difficulty of translating this passage stems from the finger gesture Lacombe makes to tell Laughlin that he should translate what he has just said. The solution was to have Lacombe announce a question asked by Laughlin, as if the former knew precisely what the latter had in mind.

Elsewhere, CE3K's French translators took advantage of certain elements in the visuals to conceal the original interpreting act. This is the case in a scene where Lacombe and Laughlin talk to Major Walsh:

Table 11: Excerpt from the meeting with Walsh scene.

\begin{tabular}{|l|l|l|l|}
\hline Character & OV & FDV & BT \\
\hline Laughlin & [Nothing] & $\begin{array}{l}\text { Il aurait voulu que } \\
\text { nous fassions } \\
\text { évacuer ces douze } \\
\text { personnes... }\end{array}$ & $\begin{array}{l}\text { He wanted us to } \\
\text { evacuate these } \\
\text { twelve people... }\end{array}$ \\
\hline Walsh & $\begin{array}{l}\text { You brought in } \\
\text { twelve people to the } \\
\text { decontamination } \\
\text { camp... }\end{array}$ & [Nothing $]$ & [Nothing] \\
\hline
\end{tabular}




\begin{tabular}{|c|c|c|c|}
\hline Laughlin & $\begin{array}{l}\ldots \text { au camp de } \\
\text { décontamination... }\end{array}$ & $\begin{array}{l}\text {... au lieu de les } \\
\text { amener ici; il faut lui } \\
\text { parler. }\end{array}$ & $\begin{array}{l}\ldots \text { instead of } \\
\text { bringing them here; } \\
\text { we have to talk to } \\
\text { him. }\end{array}$ \\
\hline Walsh & $\begin{array}{l}\ldots \text { instead of the } \\
\text { evacuation centre } \\
\text { where they belong. } \\
\text { Why? }\end{array}$ & $\begin{array}{l}\text { Eh bien, allez-y, je } \\
\text { vous écoute, } \\
\text { Messieurs. Je } \\
\text { voudrais savoir } \\
\text { pourquoi ces gens } \\
\text { sont là. }\end{array}$ & $\begin{array}{l}\text { So, go ahead, I'm } \\
\text { listening to you, } \\
\text { gentlemen. I'd like } \\
\text { to know why these } \\
\text { people are here. }\end{array}$ \\
\hline Laughlin & $\begin{array}{l}\ldots[?] \text { savoir } \\
\text { pourquoi. }\end{array}$ & $\begin{array}{l}\text { Je ne pense pas que } \\
\text { ça change quoi que } \\
\text { ce soit. }\end{array}$ & $\begin{array}{l}\text { I don't think it } \\
\text { makes any } \\
\text { difference. }\end{array}$ \\
\hline
\end{tabular}

Walsh's upper body cannot be seen at first, due to the camera angle: he is filmed from behind as he is sitting down when he starts talking; at the same time Laughlin is shown beside Lacombe, interpreting into French. The FDV's translators put Walsh's words into Laughlin's mouth, as if he had already talked to Walsh (or one of his men) before and was explaining the situation to Lacombe. When Walsh's face becomes visible, he asks Lacombe and Laughlin to give him an explanation. Laughlin then replies, making another personal comment.

The fact that Laughlin sometimes translates simultaneously instead of consecutively creates an overlap in both the OV and the FDV. In the OV Laughlin's simultaneous translations are rather inconspicuous because they are at a lower sound level than the equivalent sentences in English. Besides, since these lines are in French, an Anglophone viewer would typically focus on the English anyway. The situation is completely different in the FDV since Laughlin speaks at the same voice pitch as another character currently speaking and his words are perfectly understandable to the Francophone audience.

This phenomenon also occurs in a scene where Major Walsh receives a phone call from his superior, while Lacombe and Laughlin listen to the conversation in the background. This constitutes a factual mistake: although film conventions often enable the audience to listen to both participants of a phone conversation, Lacombe and Laughlin should not have been able to overhear the colonel's words because Walsh uses a regular receiver, not a device with speakers. There is another goof in the scene: in the OV Laughlin is supposed to translate simultaneously what he hears but in fact he is slightly ahead, which betrays the fact that actor Bob Balaban had learnt his French text by heart. Fortunately these lines are part of the audio background and can be heard only if one listens carefully. The FDV solves the problem by having Laughlin make a series of personal comments and signalling the presence of EZ4 gas cylinders 
before the colonel speaks about it again, which then prompts Lacombe to question Walsh. Walsh answers and is simultaneously interpreted by Laughlin. Lacombe replies angrily while Laughlin is still translating, which creates a real cacophony in the FDV.

Finally, another problem in the film is the presence of five subtitles that were burnt in the master copy used to make the 2001 DVD edition: although these subtitles are necessary in the OV for the audience to understand short conversations in French between Lacombe and Laughlin, they appear in the FDV too, upsetting the dub's aim to be unobtrusive. Indeed, while the Francophone viewers would accept the appearance of French subtitles as part of film conventions, the unwanted presence of English subtitles might make them wonder about the reasons for this, and distract them from the film, threatening the suspension of disbelief.

\section{Concluding remarks}

The virtually complete disappearance of heterolingualism in the FDV of $C E 3 K$ is not surprising, given that English is substituted by French and the main foreign language in the film is, in this case, the same as the language of the dubbed version.

In some audiovisual productions featuring French characters, a common strategy used to make them stand out is to give them another nationality and accent. For example, whereas the Looney Tunes character Pepé Le Pew spoke with a stereotypical French accent in the OV of the cartoons, he was given Italian inflections in the FDV, still conveying the clichés of the passionate lover. In contrast, in the Simpsons episode "Guess Who's Coming to Criticize Dinner" (Kruse, 1999), a French chef who tries to poison Homer Simpson speaks with a Russian accent in the FDV in order to suggest malevolence. In the case of $C E 3 K$, however, there is no compensation for the loss of L3: it would have been absurd to hear Lacombe/Truffaut speak with a German accent, for instance.

The loss of heterolingualism has consequences for the portrayal of Lacombe and Laughlin. In the OV, the Frenchman is a renowned ufologist who tries to communicate not only with the extra-terrestrials, but also with his American colleagues, which is why he has to rely on an interpreter. Although Lacombe fulfils the same functions as a character in the FDV, he now does not have any difficulties interacting with others; as a result, the FDV's viewers do not access the original mise en abyme. In the FDV, Lacombe is virtually always flanked by Laughlin; the latter's presence is justified by making him Lacombe's assistant, as the dialogue in Table 12 suggests: 
Table 12: Excerpt from Laughlin's introductory scene.

\begin{tabular}{|l|l|l|l|}
\hline Character & OV & FDV & BT \\
\hline $\begin{array}{l}\text { Project } \\
\text { Leader }\end{array}$ & $\begin{array}{l}\text { Is the project leader } \\
\text { with you? }\end{array}$ & $\begin{array}{l}\text { Vous comprenez } \\
\text { l'espagnol? }\end{array}$ & $\begin{array}{l}\text { Do you } \\
\text { understand } \\
\text { Spanish? }\end{array}$ \\
\hline Laughlin & $\begin{array}{l}\text { I'm not a professional } \\
\text { interpreter. My } \\
\text { occupation is } \\
\text { cartography. I'm a } \\
\text { mapmaker. }\end{array}$ & $\begin{array}{l}\text { Je pensais justement } \\
\text { que cette langue vous } \\
\text { était familière, mais } \\
\text { je crois que je saurai } \\
\text { me débrouiller. J'l'ai } \\
\text { appris à l'école. }\end{array}$ & $\begin{array}{l}\text { Actually, I } \\
\text { thought you knew } \\
\text { that language, but } \\
\text { I think I could } \\
\text { manage. I learnt it } \\
\text { at school. }\end{array}$ \\
\hline Project \\
Leader & $\begin{array}{l}\text { Can you translate } \\
\text { French into English } \\
\text { and English into } \\
\text { French? }\end{array}$ & $\begin{array}{l}\text { Vous assisterez } \\
\text { Lacombe pendant } \\
\text { notre séjour ici ou } \\
\text { durant toute } \\
\text { l'opération? }\end{array}$ & $\begin{array}{l}\text { Will you be } \\
\text { assisting Lacombe } \\
\text { during our stay } \\
\text { here or during the } \\
\text { whole operation? }\end{array}$ \\
\hline Laughlin & $\begin{array}{l}\text { Yes, yes, I just talked } \\
\text { to the team leader at } \\
\text { Villa Hermosa. I'm } \\
\text { just a little taken by } \\
\text { surprise. }\end{array}$ & $\begin{array}{l}\text { Ouais, ouais, j'ai été } \\
\text { désigné pour } \\
\text { l'assister pendant la } \\
\text { durée de l'opération, } \\
\text { oui. }\end{array}$ & $\begin{array}{l}\text { Yeah, yeah, I've } \\
\text { been picked to } \\
\text { assist him during } \\
\text { the whole } \\
\text { operation, yes. }\end{array}$ \\
\hline
\end{tabular}

In the OV Laughlin joined the project quite by accident: it is because of his good command of French that he acts as Lacombe's personal interpreter. Laughlin points out that he is a cartographer, an element that proves to be crucial later in the film as he deciphers an apparently meaningless string of digits as being the geographical coordinates of the meeting point with the extra-terrestrials at Devils Tower. Apart from that, Laughlin speaks relatively little for himself since most of his contributions are translations into English or French of what others say.

As can be seen in Table 12, in the FDV Laughlin is Lacombe's assistant, although it is never explained why the latter needed a helper. Laughlin is asked whether he understands Spanish, but the question turns out to be pointless: his interpreting skills are never called upon because in the following scene (see Table 7) the Project Leader translates the old man's sayings himself. Laughlin does not display the more reserved behaviour that one would normally expect of an assistant. He makes numerous comments in a cynical tone, dismissing arguments or even sounding aggressive in the interrogation scene (Table 8) which, in the $\mathrm{OV}$, contains only a series of neutral questions. Moreover, in this scene, Laughlin speaks a lot (because he was interpreting in the OV), which creates the impression that he, instead of his superior, Lacombe, is 
leading the interview. Laughlin's frequent additions can make the viewer feel that he always wants to have the last word. This impression is supported by the several instances of overlap (Table 11): it is as if Laughlin does not want to listen to others. To sum up, the image of the character changes radically from the OV to the FDV: while Laughlin is important both homodiegetically (as he helps Lacombe) and heterodiegetically (since he makes the use of subtitles unnecessary when French is heard) in the OV, he becomes even more prominent in the FDV, where he even appears to be autonomous from his boss.

Despite their effect on characterisation, the strategies used by the French translators to conceal the instances of interpreting in the film are very creative: the average FDV spectator would not notice that something has changed, because the dub is coherent on its own terms. The loss of the film's heterolingual nature is, then, a necessary evil among several others which are inherent to audiovisual translation; the aim here is to give the audience an enjoyable viewing experience.

\section{References}

Abend-David, D. (Ed.) (2014). Media and translation: An interdisciplinary approach. London: Bloomsbury.

Armstrong, N., \& Federici, F.M. (Eds.) (2006). Translating voices, translating regions. Rome: Aracne.

Bleichenbacher, L. (2008). Multilingualism in the movies: Hollywood characters and their language choices. Tübingen: Francke.

Corrius, M. (2008). Translating multilingual audiovisual texts: Priorities and restrictions, implications and applications. Doctoral thesis. Barcelona: Universitat Autónoma de Barcelona.

Corrius, M., \& Zabalbeascoa, P. (2011). Language variation in source texts and their translations: The case of L3 in film translation. Target, 23(1), 113-130.

Delabastita, D., \& Grutman, R. (Eds.) (2005). Fictionalising translation and multilingualism. Linguistica Antverpensia New Series 4.

Díaz Cintas, J., Matamala, A., \& Neves, J. (Eds.) (2010). New insights into audiovisual translation and media accessibility. Media for All 2. Amsterdam: Rodopi.

Gambier, Y., \& Gottlieb, H. (Eds.) (2001). (Multi) media translation: Concepts, practices, and research. Amsterdam: John Benjamins.

Labate, S. (2013a). Heterolingualism in Second World War films: The Longest Day and Saving Private Ryan. In G. González, Y. Khaled \& T. Voinova (Eds.), Emerging research in translation studies: Selected papers of the CETRA research summer school 2012. http://www.arts.kuleuven.be/cetra/papers/files/labate (consulted 12.04.2014)

Labate, S. (2013b). Le Doublage: de la théâtralité pour le cinéma. Unpublished term paper. Louvain-la-Neuve: Université Catholique de Louvain. 
Meylaerts, R. (Ed.) (2006). Heterolingualism in/and translation. Special issue of Target, 18(1).

Orero, P. (Ed.) (2004). Topics in audiovisual translation. Amsterdam: John Benjamins.

O'Sullivan, C. (2011). Translating popular film. Basingstoke: Palgrave Macmillan.

Remael, A., Orero, P., \& Carroll, M. (Eds.) (2013). Audiovisual translation and media accessibility at the crossroads. Media For All 3. Amsterdam: Rodopi.

Şerban, A., \& Lavaur, J.-M. (Eds.) (2011). Traduction et médias audiovisuels. Lille: Presses Universitaires du Septentrion.

Sternberg, M. (1981). Polylingualism as reality and translation as mimesis. Poetics Today, 2(4), 221-239.

Voellmer, E. (2012). The complexity of establishing third languages in Inglourious Basterds: Applying a model of translation analysis to dubbing. Unpublished MA thesis. Barcelona: Universitat Pompeu Fabra.

Zabalbeascoa, P. (2012). Translating heterolingual audiovisual humour: Beyond the blinkers of traditional thinking. In J. Muñoz-Basols, C. Fouto, L. Soler González \& T. Fisher (Eds.), The limits of literary translation: Expanding frontiers in Iberian languages (pp. 317-338). Kassel: Reichenberger.

\section{Filmography}

Allen, I. (Producer), \& Guillermin, J. (Director). (1974). The Towering Inferno [Motion picture]. United States: 20th Century Fox/Warner Bros.

Bender, L. (Producer), \& Tarantino, Q. (Director). (2009). Inglourious Basterds [Motion picture]. Germany/United States: The Weinstein Company/Universal Pictures.

Disney, W. (Producer), \& Hand, D. (Director). (1937). Snow White and the Seven Dwarfs [Motion picture]. United States: Walt Disney Productions.

Kennedy, K. \& Spielberg, S. (Producers), \& Spielberg, S. (Director). (1982). E.T. the Extra-Terrestrial [Motion picture]. United States: Universal Pictures.

Kurtz, G. (Producer), \& Lucas, G. (Director). (1977). Star Wars Episode IV: A New Hope [Motion picture]. United States: 20th Century Fox.

Phillips, J. \& Phillips, L. (Producers), \& Spielberg, S. (Director). (1977). Close Encounters of the Third Kind [Motion picture]. United States: Columbia Pictures.

Scully, B. (Producer), \& Kruse, N. (Director). (1999). "Guess Who's Coming to Criticize Dinner?", The Simpsons 11(3) [Cartoon]. United States: 20th Century Fox.

Zanuck, D. F. (Producer), \& Annakin, K., Marton, A., Wicki, B. \& Oswald, G. (Directors). (1962). The Longest Day [Motion picture]. United States: 20th Century Fox. 
1 I wish to thank all the people who have proofread my paper: this volume's editors, two anonymous referees, Dirk Delabastita, Lieven Vandelanotte and Elena Voellmer. Their suggestions and support have greatly improved this article.

2 Later renamed Star Wars Episode IV: A New Hope.

3 As stated in the DVD's audio commentary, Truffaut accepted to play in the film on the condition that his character could speak French. The screenplay was adapted to cater for this constraint, which had the advantage of adding a mise en abyme to the story: Lacombe finds it difficult to communicate with both humans and extra-terrestrials.

4 Fred Savdié wrote the film's first French dubbed version, while his son Joël Savdié contributed to the 2001 dub. In this paper I use the term "translators" to include all the individuals involved in the redubbing (e.g., studio representatives, stage director, voice actors) who could have had an influence on certain translation choices.

5 I considered that a new scene started whenever there was a break in the spatiotemporal continuity.

6 Whenever a French actor or actress plays in a foreign film (e.g., Gérard Depardieu and Marion Cotillard), they dub themselves in the FDVs because the French audience expects them to speak with the same voice that they are used to hearing (see Labate, 2013b).

7 The whole principle of dubbing rests on the concept of the "willing suspension of disbelief", a convention thanks to which the audience unquestioningly accepts, for instance, that the characters of a film set in Roman times speak present-day English (see also Voellmer, 2012, pp. 37-39).

8 This is the official name of the character, played by J. Patrick McNamara, as it appears in the end credits.

9 Thanks are due to Eloy Romero-Muñoz and Elena Voellmer for transcribing the lines in Spanish and answering my questions about the text. 